\title{
PENGEMBANGAN MULTIMEDIA PEMBELAJARAN INTERAKTIF KIMIA BERBASIS ANDROID MENGGUNAKAN PRINSIP MAYER PADA MATERI LAJU REAKSI
}

\author{
Dian Puspita Eka Putri 1*, Ali Muhtadi 2 \\ 1IAIN Syaikh abdurrahman siddik bangka belitung \\ 2Universitas Negeri Yogyakarta \\ 1Jl. Pahlawan 12, Petaling, Mendo Barat, Bangka, Kepulauan Bangka Belitung, Indonesia \\ 2Jl. Colombo No. 1, Depok, Sleman 55281, Yogyakarta, Indonesia \\ * Cooresponding Author. Email: dianpuspitaekap@gmail.com
}

\begin{abstract}
Abstrak
Tujuan penelitian adalah(1) mengetahui karakteristik produk multimedia yang layak untuk materi laju reaksi (2) menguji keefektivan produk dalam meningkatkan capaian hasil belajar kognitif. Penelitian dilakukan di kelas XI IPA 3 SMAN 9 Yogyakarta. Metode penelitian R \& D dari model Alessi and Trollip. Subjek uji coba adalah 3 ahli media dan 3 ahli materi pada uji alpha, 1 guru kimia dan 5 orang siswa pada uji beta, dan 30 siswa pada uji validasi. Pengumpulan data menggunakan observasi, wawancara, angket, dan tes. Data dianalisis secara deskriptif kualitatif dan perhitungan statistik. Hasil penelitian: (1) produk sangat layak (2) karakteristiknya dapat memvisualisasikan konsep laju reaksi, tersusun atas beberapa jenis media penggunaan dikontrol siswa, memenuhi perbedaan kecepatan belajar, dan dikemas dalam bentuk aplikasi berbasis android. Oleh karena itu, pembelajaran dengan produk yang dihasilkan dapat dilakukan dimana saja dan kapan saja; (3) produk terbukti efektif dalam meningkatkan capaian hasil belajar kognitif pada materi laju reaksi.

Kata kunci: multimedia pembelajaran interaktif, laju reaksi, capaian hasil belajar kognitif

\section{DEVELOPING INTERACTIVE MULTIMEDIA LEARNING CHEMISTRY BASED ON ANDROID WITH MAYER'S PRINCIPLES ON RATE REACTION COURSE}

\section{Abstract}

This study aims to: (1) determine the effectiveness of multimedia products interactive learning based on Android using the principles of Mayer viable in the material reaction rate. (2) test the effectiveness product to improve outcomes cognitive achievement of students in the material rate reaction. This research was conducted in SMAN 9 Yogyakarta by using research and development methods $(R \in \mathcal{E} D)$, followed the model Alessi and Trollip. Subject trials of investigational products were the three experts of media and three experts material on the alpha test, one chemistry teacher and 5 students grade XI students in beta test and 30 students of class XI IPA 3 SMAN 9 Yogyakarta on validity test the effectiveness of the product. The collection of data was done through observation, interviews, questionnaires, and tests. Data were analyzed by descriptive qualitative and statistical calculations. The results show: (1) the products considered to be feasible, (2) the product has characteristic can visualize the concept of reaction rate, composed of several types of media, the activity can be controlled by students, can meet the student's pace difference, can be installed on android smartphone can be done learn; (3) the product proved effective in raising the achievement of the cognitive learning.
\end{abstract}

Keywords: multimedia interactive learning, rate reaction, cognitive learning outcomes

Permalink/DOI: http://dx.doi.org/10.21831/jitp.v5i1.13752 


\section{Pendahuluan}

Kimia merupakan salah satu cabang ilmu pengetahuan alam yang ditujukan untuk siswa pada jenjang SMA/SMK/MA dan sederajat. Kimia sebagai kelompok ilmu pengetahuan dan teknologi memiliki kompetensi lanjut yang menuntut siswa memiliki pengetahuan faktual, konseptual, prosedural dan metakognitif dalam ilmu pengetahuan (Kementerian Pendidikan dan Kebudayaan Republik Indonesia, 2016). Tujuan tersebut dapat dicapai apabila seluruh komponen pembelajaran bersinergi dengan baik. Komponen tersebut dapat berupa tujuan pembelajaran, materi pembelajaran, strategi dan metode, media dan sumber, karakteristik siswa serta karakter materi kimia itu sendiri. Pemilihan strategi, metode, media, dan sumber belajar harus efektif dan efisien, serta tepat digunakan untuk menunjang pembelajaran sesuai dengan karakteristik materi dan karakteristik siswa (Degeng, 2013, pp. 216-221).

Proses pembelajaran kimia yang terjadi selama ini belum mampu mencapai tujuan pembelajaran secara optimal. Siswa masih kesulitan memahami materi pembelajaran kimia yang ada. Ada beberapa faktor yang dapat mempengaruhi hasil belajar, yaitu kompetensi guru, sistem kurikulum, siswa, media pembelajaran yang digunakan lingkungan pembelajaran serta strategi dan metode pembelajaran (Sugiyarto \& Ikhsan, 2014, p. 128). Komponen-komponen tersebut berperan penting dalam mencapai tujuan pembelajaran. Begitu juga dengan media pembelajaran, media pembelajaran merupakan faktor yang berpengaruh dalam mencapai efektivitas belajar. Oleh karena itu, untuk meningkatkan efektivitas pembelajaran kimia diperlukan sumber atau media yang baik.

Laju reaksi adalah materi pembelajaran kimia yang ditujukan untuk siswa kelas XI SMA/SMK/MA dan sederajatnya. Menurut laporan hasil belajar kimia kelas XI IPA SMAN 9 Yogyakarta (2015) diperoleh fakta, yaitu rata-rata terendah penguasaan materi pembelajaran kimia dengan kriteria ketuntasan minimum sebesar 70 dari tahun ajaran 2014/2015-2015/2016 adalah materi laju reaksi. Masalah lain terkait pembelajaran kimia khususnya materi laju reaksi yang diperoleh dari hasil obsevasi dan wawancara dengan salah satu guru kimia SMAN 9 Yogyakarta di antaranya adalah masih minimnya sumber belajar yang dapat memenuhi karakteristik materi dan karakteristik siswa.

Sejauh ini sumber belajar yang biasa digunakan berupa buku paket dan Lembar Kerja Siswa (LKS). Buku paket dan LKS yang digunakan selama ini belum mampu mengoptimalkan hasil belajar siswa. Hal ini dikarenakan buku paket dan LKS mempunyai keterbatasan dalam menyampaikan dan menghadirkan pesan isi materi laju reaksi dalam bentuk nyata. Karakteristik materi laju reaksi yang bersifat abstrak membutuhkan visualisasi yang dapat menggambarkan kejadian dan faktor-faktor yang mempengaruhi laju reaksi tersebut secara lebih real. Oleh karena itu, dibutuhkan sumber belajar dalam bentuk yang lebih nyata.

Berdasarkan wawancara yang dilakukan dengan salah satu guru kimia dan beberapa siswa di SMAN 9 Yogyakarta diketahui bahwa pembelajaran kimia saat ini sudah memakai media dalam upayanya mencapai tujuan pembelajaran, namun media tersebut dirasa belum cukup optimal. Selain itu, media tersebut kurang mampu membuat materi laju reaksi menjadi lebih konkret.

Multimedia pembelajaran interaktif berbasis android merupakan salah satu solusi yang dianggap dapat membantu permasalahan tersebut. Pengembangan multimedia berbasis android dalam penelitian ini bertujuan untuk mengoptimalkan kelebihan teknologi dalam menunjang keberhasilan pembelajaran sehingga perkembangan teknologi akan membawa dampak positif. Hal ini sejalan dengan penilitian yang dilakukan oleh (Yektyastuti, 2012, p. 13) yang menyimpulkan bahwa peningkatan efektivitas pencapaian tujuan pembelajaran terjadi apabila suatu materi yang bersifat 
abstrak dapat disajikan dalam bentuk yang lebih konkret dan realistis.

Menurut Ivers \& Barron (2010, p. 210), multimedia adalah perpaduan berbagai macam media untuk menyajikan informasi. Roblyer \& Doering (2013, pp. 172-173) menyatakan bahwa multimedia merupakan gabungan dari berbagai media seperti grafis dan fotografi, suara, video, animasi, dan teks dalam suatu produk yang tujuannya untuk mengkomunikasikan informasi dalam berbagai cara. Sementara itu, Vaughan (2006, p. 136) menyatakan bahwa multimedia ialah kombinasi dari teks, foto, seni grafis, suara, animasi, dan elemen-elemen video yang dimanipulasi secara digital. Definisi multimedia yang lain tentang multimedia juga dikemukakan oleh Mayer (2009, p. 3) yang mendefinisikan multimedia sebagai presentasi materi dengan menggunakan kata-kata sekaligus gambar. Kata adalah materi yang berbentuk verbal form (bentuk verbal) seperti teks dan narasi. Gambar adalah materi yang berbentuk pictorial form (bentuk gambar). Gambar bisa berupa grafik statis (seperti foto, grafik, ilustrasi, dan sebagainya) dan grafik dinamis (seperti animasi dan video).

Mayer (2009, p. 3) mengemukakan beberapa prinsip yang harus diperhatikan dalam pengembangan multimedia yang baik. Prinsip-prinsip tersebut adalah: (1) prinsip multimedia, (2) prinsip keterdekatan ruang, (3) prinsip keterdekatan waktu, (4) prinsip koherensi, (5) prinsip modalitas belajar, (6) prinsip redudansi, dan (7) prinsip interaktivitas.

Milovanović, Obradović, \& Milajić (2013, p. 19) menyebutkan bahwa pengembangan multimedia dengan menggunakan prinsip Mayer dapat meminimalisir kesalahan yang menyebabkan media pembelajaran tidak efektif jika dibandingkan dengan beberapa prinsip lainnya. Dengan demikian, penggunaan prinsip Mayer dalam mengembangkan multimedia pembelajaran akan dapat menghasilkan media pembelajaran yang lebih baik dan efektif.

Penggunaan multimedia pembelajaran akan lebih optimal jika didukung oleh device yang mudah digunakan, salah satunya adalah smartphone. Fenomena sistem operasi smartphone di Indonesia yang penggunaannya paling tinggi adalah sistem operasi berbasis Android. Android adalah sistem operasi yang sifatnya open lisence yang memungkinkan siapapun untuk mengembangkan berbagai aplikasi termasuk aplikasi pembelajaran. Menurut data yang di lansir pada situs gs.statcounter.com menunjukkan bahwa terjadinya peningkatan yang sangat pesat tentang penggunaan smartphone berbasis android sebanyak 49,86\% yaitu dari 18,53\% per-agustus 2012 menjadi $68,39 \%$ per-agustus 2015 . Hal ini diperkuat dengan data dari siswa SMAN 9 Yogyakarta yang menyebutkan bahwa, dari 30 orang siswa yang memiliki smartphone, terdapat sebanyak $90 \%$ menggunakan smartphone berbasis Android dan smartphone berbasis IOS sebanyak $10 \%$.

Berdasarkan uraian yang telah disampaikan tersebut, maka tujuan penelitian dan pengembangan ini, adalah untuk mengetahui karakteristik produk multimedia pembelajaran interaktif berbasis android menggunakan prinsip Mayer yang layak untuk materi laju reaksi dan menguji keefektivan produk multimedia pembelajaran interaktif kimia berbasis android menggunakan prinsip Mayer dalam meningkatkan capaian hasil belajar kognitif siswa pada materi laju reaksi.

\section{Metode Penelitian}

Metode penelitian adalah penelitian dan pengembangan atau lebih dikenal dengan istilah R \& D (Research and Development) yang mengacu pada model Alessi \& Trollip (2001, p. 410). Secara garis besar model ini mengacu pada 3 lang-kah besar yaitu planing, design, dan develop-ment.

Penelitian dilakukan pada tanggal 16-26 November 2016 di SMAN 9 Yogyakarta. Subjek penelitian adalah 3 orang ahli media, 3 orang ahli materi, guru kimia SMAN 9 Yogyakarta, dan 30 orang siswa kelas XI IPA 3 SMAN 9 Yogyakarta. 
Prosedur pada penelitian ini adalah perencanaan, desain, pengembangan, dan uji coba produk. Data yang diperoleh berupa data kualitatif dan kuantitatif. Prosedur atau kegiatan yang dilakukan adalah tahap planing, yaitu menentukan ruang lingkup materi, melakukan identitifikasi karakter siswa, mengumpulkan sumber-sumber yang mendukung, membuat dokumen perencanaan melakukan brainstorming, yaitu diskusi ide awal dengan para ahli. Kegiatan tahap desain meliputi pembuatan flowchart, pembuatan storyboard, penyiapan naskah materi. Kegiatan pada tahap pengembangan adalah menyiapkan elemen-elemen media pendukung, seperti menyiapkan gambar, animasi, audio, dan video, dilanjutkan membuat dan mengemas produk. Selanjutnya, melakukan alpha testing, melakukan revisi awal, melakukan beta testing, membuat revisi akhir, dan uji validasi produk

Data yang dikumpulkan adalah data kualitatif dan kuantitatif. Teknik pengumpulan data melalui tahap wawancara, observasi, angket, dan tes. Instrumen yang digunakan, yaitu panduan wawancara, observasi angket penilaian ahli media, angket penilaian ahli materi tes pretest dan tes posttest

Teknik pengumpulan data yang digunakan dalam penelitian ini adalah (1) teknik analisis deskriptif kualitatif. Fungsinya untuk mengumpulkan dan menyimpulkan keseluruhan data kualitatif yang diperoleh. (2) teknik analisis uji kelayakan produk, dimana langkah-langkah yang dilakukan, yaitu menyusun hasil penilaian ahli media dan ahli materi berdasarkan skala interval 4.

Tabel 1. Konversi Data Kualitatif Angket menjadi Data Interval

\begin{tabular}{ccc}
\hline \multicolumn{2}{c}{ Data Kualitatif } & Data Interval \\
\hline SL & Sangat Layak & 5 \\
L & Layak & 4 \\
KL & Kurang Layak & 2 \\
TL & Tidak Layak & 1 \\
\hline
\end{tabular}

Data dianalisis untuk menentukan klasifikasi kriteria multimedia yang dihasilkan. Berdasarkan Widoyoko (2012, pp. 111112) diperoleh rentang klasifikasi penilaian sebagaimana disajikan pada Tabel 2.

Tabel 2. Klasifikasi Penilaian

\begin{tabular}{ccc}
\hline & $\begin{array}{c}\text { Rerata Skor } \\
\text { Jawaban }\end{array}$ & Klasifikasi \\
\hline 1 & $3,26 \leq x i \leq 4,00$ & SL (Sangat layak) \\
2 & $2,52 \leq x i \leq 3,27$ & L(Layak) \\
3 & $1,76 \leq x i \leq 2,51$ & KL (Kurang Layak) \\
4 & $1,00 \leq x i \leq 1,75$ & TL (Tidak Layak) \\
\hline
\end{tabular}

Tabel pada xi diketahui dari jumlah penilaian dibagi dengan banyaknya penilai. (3) teknik analisis capaian hasil belajar kognitif siswa. Teknik analisisnya berupa membandingkan hasil pretest, posttest, dan hasil belajar laju reaksi siswa pada tahun pembelajaran sebelumnya dengan uji statistik program SPSS 23. Uji statistik yang digunakan adalah t-test. Taraf signifikan adalah 5\% dan kriteria keputusan adalah penggunaan produk memberikan perbedaan signifikan dalam meningkatkan capaian hasil belajar kognitif siswa pada materi laju reaksi dengan siswa yang tidak menggunakan produk.

\section{Hasil Penelitian dan Pembahasan}

Pada tahap perencanaan hasil yang diperoleh, yaitu materi laju reaksi. Kesimpulan yang diperoleh dari seluruh proses identifikasi karakteristik siswa ini adalah: Rata-rata umur siswa berada dikisaran 1617 tahun, sebanyak 3 orang siswa menggunakan smartphone berbasis IOS dan 27 orang menggunakan smartphone berbasis android. Selain itu, motivasi belajar siswa meningkat apabila menggunakan media yang dapat dikontrol sendiri penggunaannya. Sebagian besar siswa memiliki alat komunikasi berbasis android, kecepatan memahami materi setiap siswa berbeda-beda, dan tipe belajar yang dimiliki siswa sangat berbeda.

Penerapan prinsip Mayer pada pengembangan ini adalah: prinsip multime- 
dia, siswa dapat belajar lebih baik dari katakata dan gambar-gambar daripada ka-takata saja. Prinsip kedekatan ruang, siswa dapat belajar lebih baik saat kata-kata dan gambar-gambar terkait disajikan saling berdekatan daripada saat disajikan saling berjauhan dalam halaman atau layar. Prinsip keterdekatan waktu, siswa dapat belajar lebih baik saat kata-kata dan gambar-gambar terkait disajikan secara simultan daripada bergantian. Prinsip koherensi, siswa dapat belajar lebih baik jika materi yang tidak relevan (mengganggu) disisihkan daripada dimasukkan. Prinsip ini dijabarkan menjadi tiga versi yang saling melengkapi, yaitu: (1) pembelajaran siswa akan terganggu jika kata-kata dan gambar-gambar menarik, namun tidak relevan ditambahkan ke presentasi multimedia; (2) pembelajaran siswa terganggu jika suara dan musik menarik, namun tidak relevan ditambahkan ke presentasi multimedia; serta (3) pembelajaran siswa meningkat jika kata-kata yang tidak diperlukan, disingkirkan dari presentasi multimedia. Prinsip modalitas, siswa dapat belajar lebih baik dari animasi dan narasi daripada dari animasi dan teks on-screen, yakni siswa-siswa bisa belajar lebih baik saat kata-kata dalam pesan multimedia disajikan sebagai teks yang diucapkan daripada teks tercetak. Penerapan dalam multimedia, yaitu dengan tidak menuliskan teks pada saat video yang digunakan dalam multimedia ini ditampilkan.

Prinsip redudansi, siswa bisa belajar lebih baik dari animasi dan narasi daripada dari gabungan animasi, narasi, dan teks yang identik sama dengan narasi. Penerapan dalam multimedia yaitu dengan memberikan animasi, teks, dan narasi dalam satu frame secara bersamaan, melainkan animasi dan teks saja atau animasi dan narasi saja. Prinsip interaktivitas, siswa belajar lebih baik ketika ia dapat mengendalikan sendiri apa yang sedang dipelajarinya, bentuk interaktivitas dapat berupa self control, simulasi, games, branching. Penerapan dalam multimedia yang dihasilkan adalah pengguna bisa memilih apa yang akan mereka pelajari tanpa harus berurutan dari awal.
Karakteristik produk yang dihasilkan adalah produk dapat memvisualisasikan konsep laju reaksi yang besifat abstrak menjadi lebih konkret. Produk tersusun atas beberapa jenis media yang aktivitas penggunaannya dapat dikontrol secara mandiri oleh siswa. Produk dibuat untuk memenuhi perbedaan kecepatan belajar siswa dalam memahami materi laju reaksi. Produk dikemas dalam bentuk software aplikasi yang dapat diinstal pada smartphone android yang sering digunakan oleh siswa, sehingga pembelajaran dengan produk tersebut dapat dilakukan dimana saja dan kapan saja. Media dengan karakteristik seperti ini dapat membantu siswa dalam mencapai hasil belajar yang optimal (Nazalin \& Muhtadi, 2016, p. 233).

Setelah membuat, produk dikemas dalam bentuk software aplikasi. Lalu, dilakukan ujicoba produk untuk mengetahui kelayakan dan kefektivan produk. Proses pengujian produk dilakukan pada tahap alpha testing, beta testing, dan validasi produk.

Pada tahap alpha testing, validasi ahli media dilakukan oleh 2 orang dosen Teknologi Pembelajaran Universitas Negeri Yogyakarta dan 1 orang pakar ahli media. Penilaian difokuskan pada aspek tampilan dan aspek pemrograman. Penilaian menggunakan angket skala 4 dengan ketentuan: 1 jika produk kurang layak untuk digunakan, 2 jika produk cukup layak untuk digunakan, 3 jika produk layak digunakan, dan 4 jika produk sangat layak untuk digunakan. Berdasarkan penilaian diperoleh rerata penilaian ahli media adalah 3,42 dengan kategori sangat layak.

Kriteria penilaian multimedia pada aspek tampilan didasari oleh pendapat yang dikemukakan oleh Philips (1997, p. 79) dan Mayer (2009, pp. 157-162), meliputi: tata letak teks, grafik, warna, animasi, suara dan bagaimana menempatkam elemen media tersebut agar dapat menjadi penyalur pesan yang baik, bukan menjadi penggangu penyampaian pesan. Hal ini sesuai dengan salah satu karakteristik multimedia pembelajaran yang dikemukakan oleh Munir (2015, 
p. 64), yaitu multimedia yang dibuat (multimedia by design) harus memenuhi unsur keindahan (estetika) dalam bentuk, warna dan kombinasinya serta rapi dalam pembuatannya. Hal ini sejalan dengan yang dikemukakan oleh Malik \& Agarwal (2012, p. 465) bahwa pemakaian berbagai jenis media seperti audio, video, gambar, dan sebagainya dalam multimedia harus ditata secara serasi dan seimbang dengan tidak mengabaikan unsur artistik dan estetikanya.

Kriteria penilaian multimedia pada aspek pemrograman didasari oleh pendapat Alessi \& Trollip (2001, pp. 53-54) bahwa multimedia yang baik adalah multimedia yang memiliki struktur navigasi yang baik, konsisten tempat dan bentuknya. Hal ini sesuai dengan pendapat Joshi, Shete, \& Somani $(2015$, p. 253) yang mengemukakan bahwa multimedia pembelajaran memiliki karakteristik mandiri yang artinya multimedia yang digunakan dapat memberi kemudahan kepada pengguna untuk menggunakan multimedia tanpa bimbingan orang lain. Hal ini didukung oleh Martono \& Nurhayati (2014, p. 170), multimedia harus dirancang agar dapat digunakan oleh siapa saja.

Validasi ahli materi dalam penelitian ini adalah dosen jurusan Pendidikan Kimia Pascasarjana Universitas Negeri Yogyakarta dan dosen Universitas Islam Negeri Sultan Syarif Kasim. Validasi yang dilakukan oleh ahli materi difokuskan pada aspek pembelajaran dan isi materi. Penilaian menggunakan angket skala 4 dengan ketentuan skor 1 jika produk dinilai kurang layak untuk digunakan, 2 jika produk cukup layak untuk digunakan, 3 jika produk layak digunakan dan 4 jika produk sangat layak untuk digunakan. Rerata penilaian ahli materi 3,83 dengan kategori sangat layak.

Kriteria penilaian multimedia oleh ahli materi didasari oleh pendapat Tan \& Wong (2003, p. 143) dan Heinick, Molenda, Russell, \& Smaldino (1996, p. 47). Pada uji beta testing, respondennya adalah 5 orang siswa dan salah guru kimia kelas XI IPA SMAN 9 Yogyakarta. Sebanyak 5 orang siswa tersebut mewakili masing-masing kelas
XI kelompok belajar IPA. Pengambilan responden didasarkan pada prestasi belajar siswa yang diperoleh dari guru bidang studi. Masing-masing responden memiliki peringkat pertama di kelas. Adapun aspek yang dinilai oleh responden uji beta adalah aspek pembelajaran, materi dan tampilan. Penilaian menggunakan angket skala 4 dengan ketentuan skor 1 jika produk dinilai kurang layak untuk digunakan, 2 jika produk cukup layak untuk digunakan, 3 jika produk layak digunakan dan 4 jika produk sangat layak untuk digunakan. Hasil rerata responden uji beta 3,81 dengan kategori sangat layak. Validasi produk terhadap 30 orang siswa SMAN 9 Yogyakarta diperoleh rerata kelayakan 3,77 dengan kategori sangat layak.

Perolehan nilai ini menunjukkan multimedia pembelajaran interaktif yang dikembangkan sudah layak digunakan sebagai media pembelajaran kimia pada materi laju reaksi dengan melakukan perbaikan pada bagian-bagian sesuai saran dari para ahli materi. Hal ini sesuai dengan fungsi multimedia pembelajaran yang dikemukakan oleh Jangathe \& Rojatkhar (2015, p. 135) yaitu multimedia pembelajaran yang digunakan dapat menanamkan konsep benar, nyata, dan tepat.

Analisis data capaian hasil belajar kognitif ini dilakukan untuk mengetahui sejauh mana tingkat pencapaian hasil belajar kognitif siswa pada materi laju reaksi. Data capaian hasil belajar kognitif siswa dapat dilihat dari pencapaian hasil belajar yang diperoleh siswa setelah menggunakan multimedia pembelajaran interaktif kimia berbasis android (posttest). Uji ini dilakukan terhadap 30 orang siswa kelas XI IPA 3 SMAN 9 Yogyakarta yang dipilih secara acak. Sebelum menggunakan produk, siswa diberikan tes (pretest) untuk melihat pengetahuan siswa sebelum menggunakan produk.

Adapun skor kompetensi minimal yang harus dikuasai oleh siswa pada materi laju reaksi di SMAN 9 Yogyakarta adalah $\geq$ 70. Data hasil belajar kognitif pada saat pretest dan post-test disajikan pada Gambar 1. 


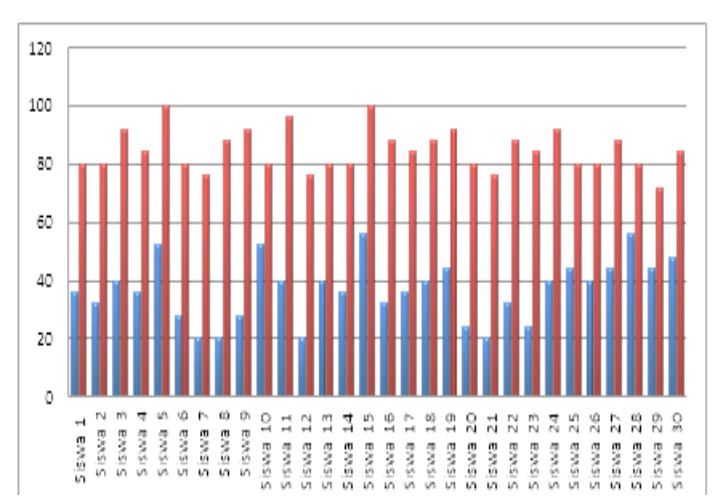

Gambar 1. Perbandingan hasil pre test dan post test

Berdasarkan data yang diperoleh, didapati bahwa rata-rata nilai pretest siswa sebelum menggunakan bantuan multimedia pembelajaran interaktif berbasis android adalah 36,80. Hasil posttest siswa setelah menggunakan multimedia pembelajaran interaktif berbasis android adalah 84,69. Keseluruhan siswa (100\%) memperoleh capaian hasil belajar kognitif melewati nilai ketuntasan minimum (KKM) yaitu $\geq 70$. Hal ini menunjukkan bahwa produk yang digunakan dapat meningkatkan capaian hasil belajar kognitif siswa pada materi laju reaksi.

Bukti lain yang juga dapat memperkuat simpulan di atas adalah ketika hasil belajar kognitif siswa yang menggunakan bantuan belajar dengan multimedia pembelajaran interaktif berbasis android ini dibandingkan dengan hasil belajar tahun sebelumnya, dimana siswa sebelumnya belum menggunakan multimedia pembelajaran interaktif kimia berbasis android namun telah sama-sama mendapatkan materi pembelajaran laju reaksi. Rerata hasil belajar tahun lalu untuk materi laju reaksi adalah 55,42 dan hasil belajar dengan bantuan media adalah 84,67 dengan kondisi pembanding sama dengan kondisi yang dibandingkan, yaitu jumlah siswa yang sama yakni 30 orang siswa, dibimbing oleh guru yang sama dan waktu pembelajaran juga sama.

Kedua data tersebut dianalisis menggunakan program SPSS 23 dengan uji statistik paired sample t-test. Taraf signifikansi yang digunakan adalah $a=5 \%$ (Sudjana,
2005, p. 231), dengan kriteria keputusan, yaitu produk memberikan peningkatan yang signifikan dalam meningkatkan capaian hasil belajar kognitif siswa pada materi laju reaksi apabila signifikansi lebih besar dari taraf signifikansi $5 \%$.

Berdasarkan hasil analisis uji signifikan yang telah dilakukan diperoleh nilai signifikansi, yaitu 0,710 lebih besar daripada taraf signifikansi 5\%. Hal tersebut menunjukkan bahwa produk multimedia pembelajaran interaktif kimia berbasis android menggunakan prinsip Mayer memberikan peningkatan yang signifikan dalam meningkatkan capaian hasil belajar kognitif siswa. Oleh karena itu, terbukti produk multimedia pembelajaran interaktif kimia berbasis android menggunakan prinsip Mayer dapat meningkatkan capaian hasil belajar kognitif siswa.

Berdasarkan rangkaian hasil uji coba produk yang dihasilkan terbukti bahwa produk layak untuk digunakan dalam pembelajaran kimia materi laju reaksi berdasarkan uji kelayakan menurut ahli media dan ahli materi. Produk yang dihasilkan juga dapat meningkatkan capaian hasil belajar kognitif siswa pada materi laju reaksi. Terbukti dengan $100 \%$ siswa mencapai hasil belajar lebih besar dari angka KKM (70) dengan rata-rata capaian hasil belajar kognitif siswa sebesar 84, 67. Serta dengan uji statistik paired sample t-test yang menunjukkan peningkatan capaian hasil belajar siswa setelah menggunakan produk multimedia pembelajaran interaktif berbasis android menggunakan prinsip Mayer adalah signifikan.

Hal ini disebabkan dalam pengembangan multimedia prinsip-prinsip multimedia yang baik telah diterapkan, seperti penggunaan prinsip Mayer (2009). Oleh karena itu, multimedia yang digunakan dalam produk ini dapat memvisualisasikan materi laju reaksi yang bersifat abstrak menjadi lebih konkret. Hal ini menjadikan penggunaan produk mendukung penyampaian materi dan membuat siswa lebih mudah untuk memahami materi laju reaksi. 
Penggunaan produk juga dapat dikontrol oleh siswa, memberikan kebebasan kepada siswa untuk memahami materi sesuai dengan kecepatan belajar yang siswa miliki. Hal ini sesuai dengan pendapat Babiker (2015, p. 66), manfaat penggunaan multimedia pembelajaran berpotensi untuk menciptakan gaya belajar multisensory dan pada saat yang bersamaan mendorong siswa untuk mengeluarkan gaya belajar mereka sebanyak mungkin. Peran multimedia tampak pada pembelajaran mandiri yang memberi ruang gerak bagi siswa untuk aktif membangun pengetahuan, keterampilan, dan sikap mereka. Hal ini didukung oleh pendapat Darmawan (2011), dengan menggunakan multimedia siswa dapat memilih apa yang dikehendakinya karena terdapat alat pengontrol seperti tombol di dalamnya.

Kelebihan produk multimedia pembelajaran interaktif kimia berbasis android materi laju reaksi yang dihasilkan antara lain: (1) dalam penyajian terdapat penggabungan berbagai unsur multimedia (teks, gambar, suara, video, dan interaktivitas) yang membantu siswa untuk aktif mengonstruksi sendiri pengetahuan, pemahaman mereka, membuat program multimedia pembelajaran ini menarik, dan menambah motivasi belajar siswa; (2) File multimedia ini berbentuk aplikasi (*.apk) yang dapat diinstall pada smartphone siswa, sehingga dapat langsung digunakan kapan saja dan dimana saja; (3) terdapat feedback/umpan balik di dalamnya, sehingga siswa termotivasi akibat adanya penghargaan yang diberikan; (4) multimedia pembelajaran ini membantu guru dalam memvisualisasikan materi laju reaksi yang bersifat abstrak; (5) aktivitas belajar dapat dikontrol sendiri oleh siswa; (6) siswa dapat belajar sesuai kemampuan dan kecepatannya masing-masing dalam memahami pengetahuan dan informasi yang disajikan; (7) siswa mendapat fasilitas untuk mengulang pembelajaran kapan saja dan dimana saja, dalam pengulangan tersebut siswa dapat mengembangkan kreativitasnya.

\section{Simpulan}

Berdasarkan uraian hasil penelitian dan pembahasan, maka disamapaikan simpulan sebagai berikut. Produk yang dihasilkan berupa aplikasi software multimedia pembelajaran interaktif kimia berbasis android materi laju reaksi yang mencakup halaman identitas, menu, petunjuk, kompetensi, materi, evaluasi, games dan profil pengembang. Berdasarkan penilaian 3 orang ahli media, 3 orang ahli materi, responden uji beta, dan responden uji validasi produk multimedia pembelajaran interaktif kimia berbasis android menggunakan prinsip Mayer dinilai sangat layak digunakan sebagai salah satu alat bantu pembelajaran kimia pada materi laju reaksi.

Karakteristik produk, yaitu produk dapat memvisualisasikan konsep laju reaksi yang bersifat abstrak menjadi lebih konkret, tersusun atas beberapa jenis media yang aktivitas penggunaannya dapat dikontrol secara mandiri oleh siswa. Selain itu, produk dibuat untuk memenuhi perbedaan kecepatan belajar siswa dalam memahami materi laju reaksi, dikemas dalam bentuk software aplikasi yang dapat diinstal pada smartphone android yang sering digunakan oleh siswa, sehingga pembelajaran dapat dilakukan dimana saja dan kapan saja.

Produk multimedia yang dihasilkan terbukti efektif untuk meningkatkan capaian hasil belajar kognitif siswa pada materi laju reaksi. Hal ini ditinjau dari hasil uji posttest dan uji statistik

Berdasarkan uraian simpulan penelitian tersebut, maka disampaikan saran sebagai berikut. Multimedia pembelajaran interaktif berbasis android dapat digunakan sebagai salah satu sumber ataupun media belajar bagi siswa. Selain itu, dapat disebarluaskan di sekolah-sekolah SMA/MA sederajat secara langsung ataupun secara elektronik melalui media internet yang diunduh, diduplikasi atau dikemas menggunakan CD bagi siapa saja yang membutuhkan.

Penelitian dan pengembangan lebih lanjut hendaknya dapat memperhatikan ke- 
butuhan siswa sehingga dapat membantu dan memberikan kontribusi besar dalam meningkatkan pemahaman konsep dan menghilangkan pemikiran siswa tentang konsep belajar kimia yang sulit, materi yang bersifat abstrak, serta tidak menarik. Selain itu, dapat menambahkan kelengkapan komponen yang belum tersedia seperti penambahan bidang evaluasi yang dapat melihat peningkatan hasil belajar afektif dan psikomotor siswa.

\section{Daftar Pustaka}

Alessi, S. M., \& Trollip, S. P. (2001). Multimedia for learning: methods and development (3rd ed.). Boston: Allyn and Bacon.

Babiker, M. E. A. (2015). For effective use of multimedia in education, teachersmust develop their own educational multimedia applications. TOJET: The Turkish Online Journal of Educational Technology, 14(4), 62-68. Retrieved from http://www.tojet.net/articles/v14i4/ 1446.pdf

Darmawan, D. (2011). Teknologi pembelajaran. Bandung: PT. Remaja Rosda Karya.

Degeng, I. N. S. (2013). Ilmu pembelajaran klasifikasi variabel untuk pengembangan teori dan penelitian. Bandung: Kalam Hidup.

Heinick, R., Molenda, M., Russell, J. D., \& Smaldino, S. E. (1996). Instructional media and technologies for learning. Upper Sadle River: Prentice Hall.

Ivers, K., \& Barron, A. (2010). Multimedia projects in education: designing, producing, and assessing. Westport: Libraries Unlimited.

Jangathe, G., \& Rojatkhar, D. (2015). Use of android in education. International Journal of Electrical and Electronics Research, 3(4), 133-137.

Joshi, R., Shete, V. V., \& Somani, S. B.
(2015). Android based smart learning and attendance management system. International Journal of Advanced Research in Computer and Communication Engineering, 4(6), 256260.

https:// doi.org/10.17148/IJARCCE.2 015.4655

Kementerian Pendidikan dan Kebudayaan Republik Indonesia. Peraturan Menteri Pendidikan dan Kebudayaan Nomor 20 Tahun 2016 tentang Standar Kompetensi Lulusan Pendidikan Dasar dan Menengah (2016).

Malik, S., \& Agarwal, A. (2012). Use of multimedia as a new educational technology tool-a study. International Journal of Information and Education Technology, 468-471. https:/ / doi.org/10.7763/IJIET.2012.V 2.181

Martono, K. T., \& Nurhayati, O. D. (2014). Implementation of android based mobile learning application as a flexible learning media. IJCSI International Journal of Computer Science Issues, 11(3). Retrieved from https:/ /ijcsi.org/papers/IJCSI-11-3-1168-174.pdf

Mayer, R. E. (2009). Multimedia learning prinsip-prinsip dan aplikasi. (T. W. Utomo, Trans.). New York: Cambrigde University Press.

Milovanović, M., Obradović, J., \& Milajić, A. (2013). Application of interactive multimedia tools in teaching mathematics - examples of lessons from geometry. TOJET: The Turkish Online Journal of Educational Technology, 12(1), 19-31. Retrieved from http://www.tojet.net/articles/v12i1/ 1213.pdf

Munir, M. (2015). The use of multimedia learning resource sharing (MLRS) in developing sharing knowledge at schools. International Journal of 
Multimedia and Ubiquitous Engineering, 10(9), 61-68.

https:// doi.org/10.14257/ijmue.2015. 10.9.07

Nazalin, N., \& Muhtadi, A. (2016).

Pengembangan multimedia interaktif pembelajaran kimia pada materi hidrokarbon untuk siswa kelas XI SMA. Jurnal Inovasi Teknologi Pendidikan, 3(2), 221. https://doi.org/10.21831/jitp.v3i2.73 59

Philips, R. (1997). The developer's handbook to interactive multimedia: a practical guide for educational applications. New York: Kogan Page, Ltd. https:// doi.org/10.1.1.183.7898

Roblyer, M., \& Doering, A. D. (2013). Integrating educational technology into teaching. New York: Pearson Education, Inc.

Sudjana, N. (2005). Penilaian hasil proses belajar mengajar. Bandung: PT Remaja Rosdakarya.

Sugiyarto, K. H., \& Ikhsan, J. (2014). Pengembangan media mobile learning
"Chem Edu" berbasis android sebagai suplemen materi kimia berdasarkan kurikulum 2013 untuk meningkatkan academic performance peserta didik $S M A / M A$. Yogyakarta.

Tan, S. C., \& Wong, A. F. L. (2003). Teaching and learning with technology. Singapore: Prentice Hall.

Vaughan, T. (2006). Multimedia: making it works. (A. Prabawati \& A. H. Triyuliana, Trans.) (8th ed.). New York: McGraw Hill Education.

Widoyoko, E. P. (2012). Teknik penyusunan instrumen penelitian. Yogyakarta: Pustaka Pelajar.

Yektyastuti, R. (2012). Pengembangan media pembelajaran Kimia berbasis Android pada materi kelarutan dan hasil kali kelarutan untuk meningkatkan motivasi belajar dan hasil belajar kognitif peserta didik SMA. Jurnal Pembelajran Kimia, 3(2), 815. 